\title{
Smokeless Tobacco Extract (STE)-Induced Toxicity in Mammalian Cells is Mediated by the Disruption of Cellular Microtubule Network: A Key Mechanism of Cytotoxicity
}

\author{
Amlan Das', Abhijit Bhattacharya', Subhendu Chakrabarty, Arnab Ganguli, Gopal Chakrabarti*
}

Department of Biotechnology and Dr. B.C. Guha Centre for Genetic Engineering and Biotechnology, University of Calcutta, WB, India

\begin{abstract}
Smokeless tobacco usage is a growing public health problem worldwide. The molecular mechanism(s) underlying smokeless tobacco associated tissue damage remain largely unidentified. In the present study we have tried to explore the effects of aqueous extract of smokeless tobacco (STE) on tubulin-microtubule, the major cytoskeleton protein that maintains cells morphology and participates in cell division. Exposure to STE resulted in dose-dependent cytotoxicity in a variety of mammalian transformed cell lines such as human lung epithelial cells A549, human liver epithelial cells HepG2, and mouse squamous epithelial cells HCC7, as well as non-tumorogenic human peripheral blood mononuclear cells PBMC. Cellular morphology of STE-treated cells was altered and the associated disruption of microtubule network indicates that STE targets tubulin-microtubule system in both cell lines. Furthermore it was also observed that STE-treatment resulted in the selective degradation of cellular tubulin, whereas actin remains unaltered. In vitro, polymerization of purified tubulin was inhibited by STE with the $\mathrm{IC}_{50}$ value $\sim 150 \mu \mathrm{g} / \mathrm{ml}$ and this is associated with the loss of reactive cysteine residues of tubulin. Application of thiol-based antioxidant N-acetyl cysteine (NAC) significantly abrogates STE-mediated microtubule damage and associated cytotoxicity in both A549 and HepG2 cells. These results suggest that microtubule damage is one of the key mechanisms of STE-induced cytotoxity in mammalian cells.
\end{abstract}

Citation: Das A, Bhattacharya A, Chakrabarty S, Ganguli A, Chakrabarti G (2013) Smokeless Tobacco Extract (STE)-Induced Toxicity in Mammalian Cells is Mediated by the Disruption of Cellular Microtubule Network: A Key Mechanism of Cytotoxicity. PLoS ONE 8(7): e68224. doi:10.1371/journal.pone.0068224

Editor: Andreas Villunger, Innsbruck Medical University, Austria

Received February 14, 2013; Accepted May 28, 2013; Published July 11, 2013

Copyright: (c) 2013 Das et al. This is an open-access article distributed under the terms of the Creative Commons Attribution License, which permits unrestricted use, distribution, and reproduction in any medium, provided the original author and source are credited.

Funding: The study was supported by Grants from Council of Scientific Industrial Research, Government of India [Grant No. 37(1216)/05/EMR-II] and Board of Research Nuclear Sciences/Department of Atomic Energy Government of India [Grant No. 2006/37/21/BRNS] to GC. The funders had no role in study design, data collection and analysis, decision to publish, or preparation of the manuscript.

Competing Interests: The authors have declared that no competing interests exist.

*E-mail: gcbcg@caluniv.ac.in

9 These authors contributed equally to this work.

\section{Introduction}

Consumption of smokeless tobacco (ST) as "spit tobacco" or "chewing tobacco" has become a world wide concern for human health due to its increasing adverse effects. Compared to the western world, usage of ST was reported to be more prevalent in South Asian countries [1], although recent studies had revealed the world wide usage of ST-related products [2,3]. Chewing tobacco, which is predominantly used in India and also in USA, is mixed with betel leaves, areca nut, lime, and catechu and is sold as legally commercial products termed "gutkha." [4]. The placement of ST in mouth, either snuff or chewing tobacco, is known to induce wrinkled changes in the oral mucosa, associated with oral injury and inflammation and may lead to Snuff dipper's lesion, also referred to as leukoplakia. It is characterized by an increased prevalence of gingival recession with associated attachment loss, cervical abrasion, and damage of the oral tissues [1]. Usage of ST may also play a contributory role in the development of cardiovascular disease, peripheral vascular disease, hypertension, peptic ulcers, and fetal morbidity and mortality [5]. Compared to the non users, increased incidence of cardiovascular, renal, and respiratory diseases have been observed in ST-users, as revealed by epidemic studies [6].

Smokeless tobacco consists of huge number of toxicants and carcinogens, which are responsible for its adverse health effects $[7,8]$. The tobacco-specific nitrosamines (TSNA) are considered to be the most potent among 28 known carcinogens in smokeless tobacco (National Cancer Institute, 1992), due to its strong carcinogenicity $[8,9]$. Beside the toxic chemicals like polycyclic aromatic hydrocarbons, nitrite, nitrate, nicotine, formaldehyde, acetaldehyde, acrolein, crotonaldehyde etc are also reported to be present in the smokeless tobacco [10,11]. Their have been several reports regarding STE-induced cytotoxicity [12-14], but the exact molecular mechanism is still uncertain. Exposure to STE is known to cause cell death and apoptosis in several cultured cell lines including oral keratinocytes [12,15], and macrophages [16].

Previously we have demonstrated that tubulin, the major cytoskeleton protein participating in diverse cellular functions, acts as a potential target for various cytotoxic agents [17-19]. Tubulin dimers polymerize to form microtubules, which further mediate cellular processes, such as cell signaling, cell motility, organelle transport, and maintenance of cell polarity, separation of 
the duplicated centrosomes, and in cell division [20-23]. It is reported that tubulin acts a potential target for the oxidative damage in the pathogenesis of several neurodegenerative diseases including Alzheimer's disease (AD) [24] and Parkinson's disease [25], Atherosclerosis [26] and lung emphysema [17]. Tubulin heterodimers as well as cellular microtubules were also found to be potential targets for various cytotoxic agents like rotenone [27], 1,4 benzoquinone [18], acenapthenequinone [19], peroxynitrite [28], and cigarette smoke $[17,26,29]$, which finally lead to the cellular apoptosis. Presence of 20 reactive cysteine residues in tubulin, makes the protein more susceptible to oxidation or chemical modification $[17,28]$ and this leads to the proteosomal degradation of the protein [30]. In our previous reports, we have shown that aqueous extract of cigarette smoke (AECS) and parabenzoquinone (PBQ), the major component of cigarette smoke, induced microtubule disruption and apoptosis in lung epithelial by targeting tubulin-sulfhydrils $[17,18]$, but the other cytoskeleton protein actin remained unaffected.

The aqueous extract of ST formed with the saliva after consumption is not only absorbed locally but also ingested and enters into the systemic circulation. It has been reported that oral administration of the aqueous extract of smokeless tobacco to male rats, resulted in the apoptosis and damage of lung, liver and kidney tissues, along with the significant up regulation of pro-apoptotic and inflammatory genes [14,31]. Since liver acts as the main site of metabolism of any foreign substance, the extent of exposure and chances of damages are quite high for the hepatic tissues. Thus the precise health effects of ST may not necessarily be limited to oral tissue injury, but rather may induce a systemic toxicity, when taken for a considerable long period of time. A major systemic catastrophe mediated by STE includes damages of hepatic and lung structural and functional devices [31]. Thus in the present study we have tried to delineate a common mechanism of STEinduced cellular toxicity. To visualize the larger spectrum of the cytotoxicity mechanism(s), we have selected human liver epithelium cells (HepG2) and human lung epithelium cells (A549) as in vitro models. Since the cell lines used are transformed in nature and may not exactly mimic the normal physiological condition, to assess the cytotoxicity of STE on normal cells, we investigated the cytotoxic effects of STE on a non-tumorigenic cell line PBMC (human peripheral blood mononuclear cells). It has been reported that, STE-treatment resulted in the generation of ROS in mammalian cells $[12,13]$. The other probable mechanisms of cytotoxicity were investigated in the present study. Since tubulinmicrotubule acts as a potential target for various cytotoxic agents, the intracellular status of microtubules in the absence and presence of different concentrations of STE were examined with both A549
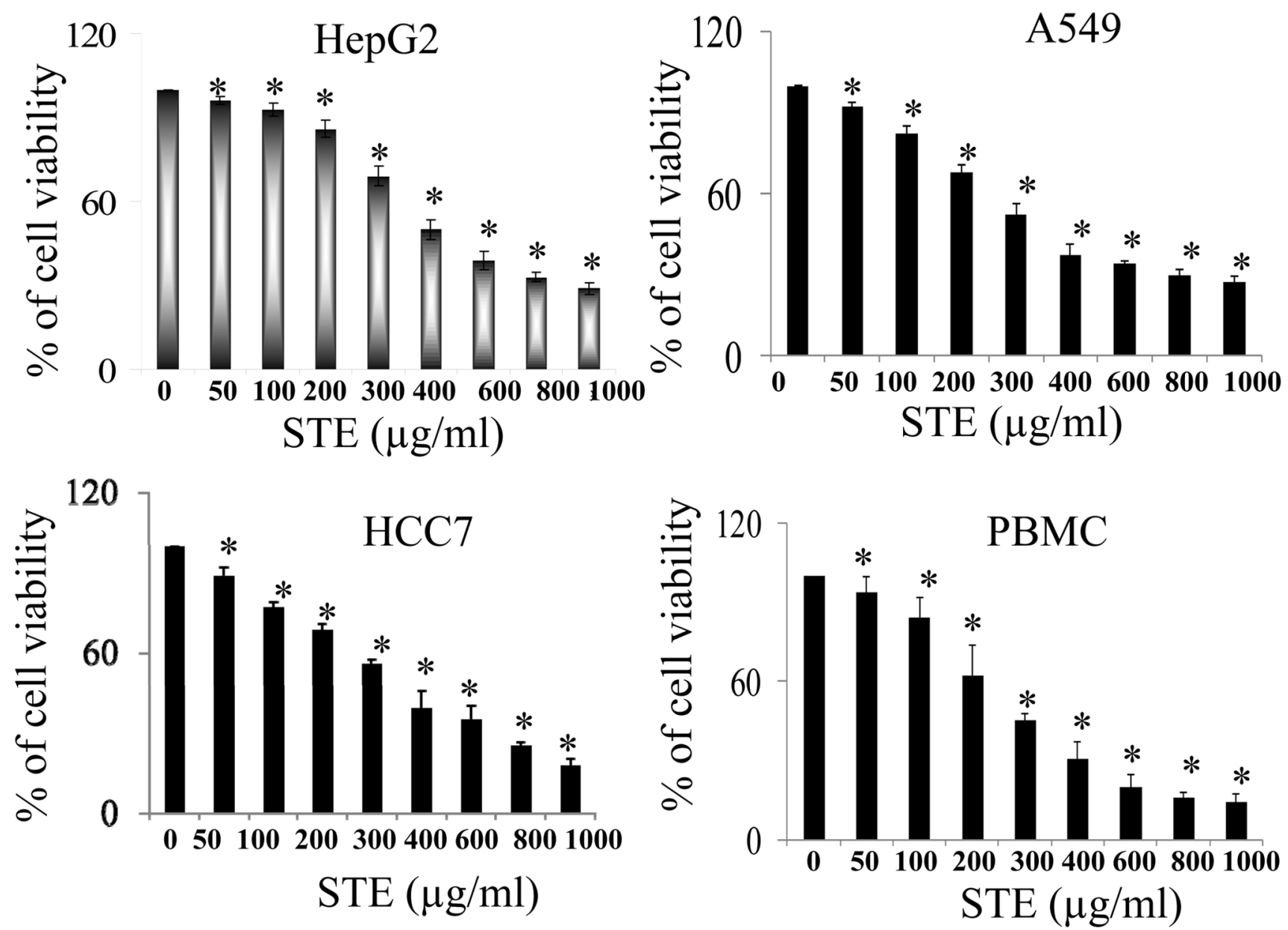

Figure 1. Induction of cytotoxicity in mammalian cells by STE. Cultured mammalian cells were incubated in the absence and presence of different doses of STE ( 0 to $1000 \mu \mathrm{g} / \mathrm{ml}$ of STE) for $48 \mathrm{~h}$ and cell viability was determined by MTT assay. Data are represented as the mean \pm SEM $\left[{ }^{*} \mathrm{P}<0.05\right.$ vs control (STE-untreated cell), where $\left.n=4\right]$. doi:10.1371/journal.pone.0068224.g001 

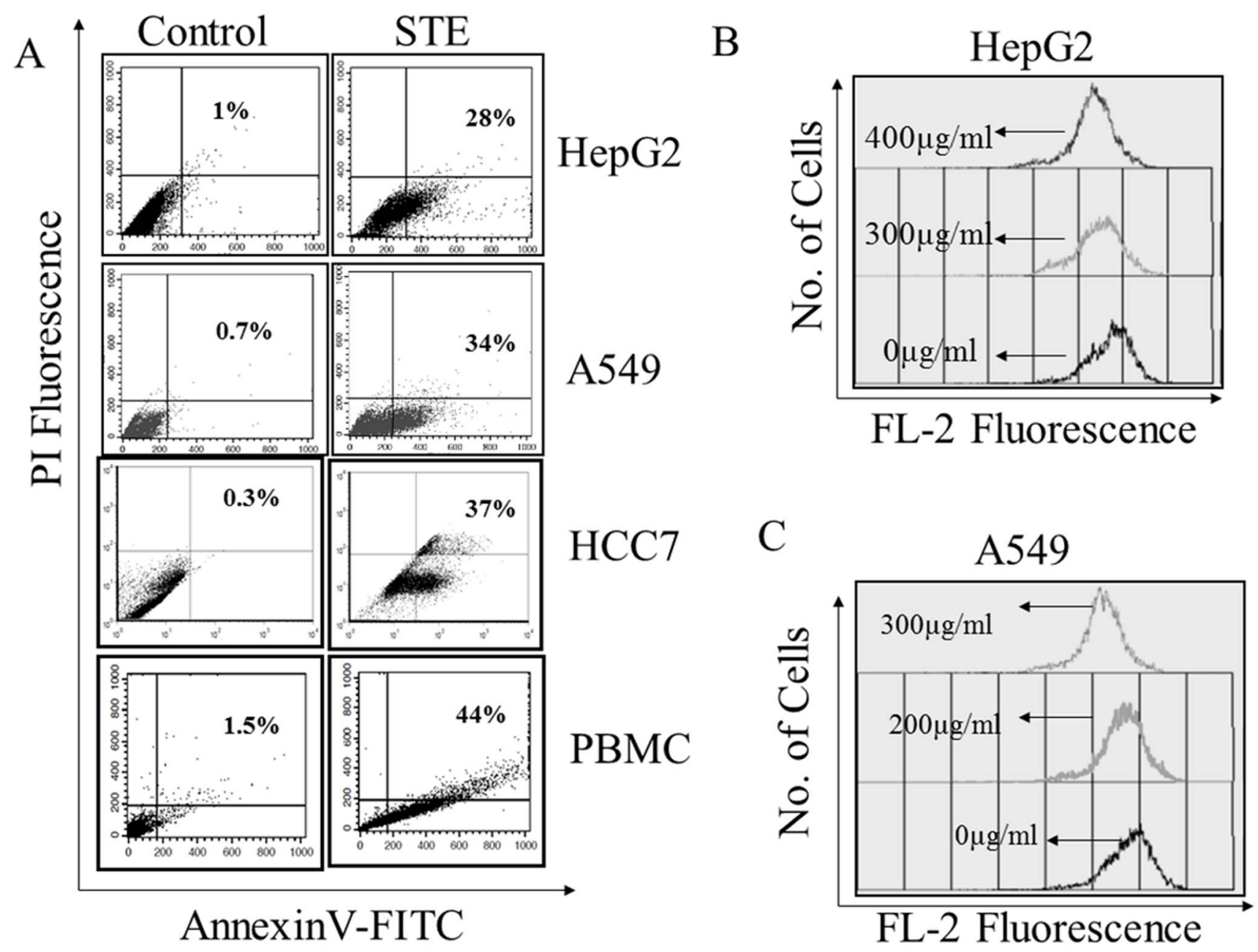

Figure 2. Induction of apoptosis and loss of mitochondrial membrane potential (MMP) in STE- treated cultured cells. (A) Induction of apoptosis in STE-treated mammalian cells was determined by annexin V-FITC and PI double staining. Apoptotic cells were analyzed flow cytometrically, and a dot plot representation of annexin-V-FITC-fluorescence ( $x$-axis) vs PI-fluorescence ( $y$-axis) has been displayed. Mitochondrial membrane potential in STE-treated HepG2 cells (B) and A549 cells (C) were monitored flow cytometrically by using the fluorescent probe Rhodamine 123. MMP was determined using a FACS Calibur flow cytometer (BD) with excitation at 488 and emission at $535 \mathrm{~nm}$. Results are expressed as a histogram analysis, average of three experiments with SEM $[\mathrm{P}<0.05$ vs control (STE-untreated cell), $\mathrm{n}=3]$.

doi:10.1371/journal.pone.0068224.g002

and HepG2 cell lines. Beside the direct effect STE on purified tubulin was also investigated.

\section{Materials and Methods}

\section{Materials}

Nutrient mixture DMEM (supplemented with L-glutamine and sodium pyruvate), Penicillin- streptomycin, Amphotericin B, Trypsin-Versene (1X) and FBS were purchased from GIBCOInvitrogen, USA. Guanosine 5'-triphosphate (GTP), PIPES, $\mathrm{MgCl}_{2}$, EGTA 5, 5'-dithiobis (2-nitrobenzoic acid) (DTNB), and FITC-conjugated monoclonal anti $\alpha$-Tubulin antibody (raised in mouse), were purchased from SIGMA, USA. Hepatocellular carcinoma (HepG2) and Lung adenocarcinoma (A549) cells were obtained from National Centre for Cell Sciences, Pune, India. Mouse oral squamous epithelium carcinoma cell line was generous gift from Dr Bipul K Acharya, Weill Cornell Medical College, Cornell University, New York, USA. Bradford protein estimation kit was purchased from GeNei, India. $\mathrm{N}$ acetyl cysteine (NAC) was purchased from Sigma and it was dissolved in Phosphate buffer
Saline (PBS) pH 7.4. All other chemicals and reagents were purchased from Sisco Research Laboratories, India.

\section{Preparation of Aqueous Extract of Smokeless Tobacco (STE) Solution}

Aqueous extract of smokeless tobacco (khaini) (STE) was prepared as described by Mitchell et al., in [13], with certain modifications. Briefly, $50 \mathrm{ml}$ PBS buffer was added to $10 \mathrm{gm}$ of commercially available smokeless tobacco (brand name Raja Khaini, one of the top selling brands in India), and the mixture was incubated for $24 \mathrm{~h}$ at $37^{\circ} \mathrm{C}$. It was then filtered first through Whatman filter paper, and subsequently through a $0.22 \mu$ membrane filter paper in sterile condition and $\mathrm{pH}$ is adjusted to 7 using $1 \mathrm{M} \mathrm{NaOH}$. The sterile filtrate was then lyophilized to the powdered form. Fresh stocks of STE were prepared from that lyophilized powder in sterile PBS as per experimental requirement. 
A

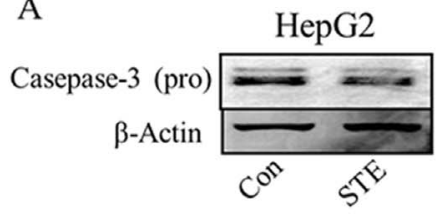

C

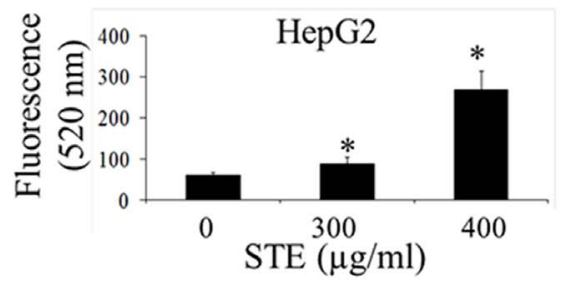

B

Casepase-3 (pro)

$\beta$-Actin

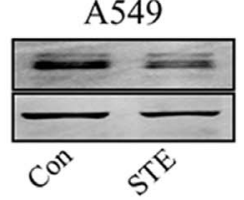

$\mathrm{D}$

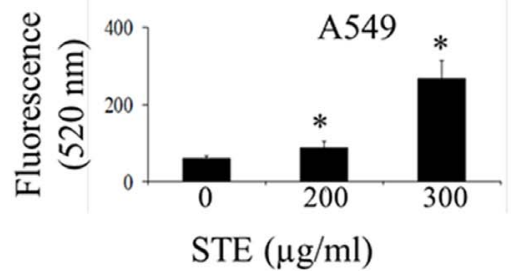

Figure 3. Activation of caspase-3 in STE- treated HepG2 and A549 cells. Activation of caspase -3 in STE-treated HepG2 cells and A549 cells was determined by western blot and fluorescence based assay. Status of pro-caspase-3 in STE (IC 50 dose)-treated cell lines was determined by western blotting (A \& B). Activity of caspase-3 in STE-treated HepG2 cells (C) and A549 cells (D), were determined by measuring the green fluorescence of the carboxyfluorescein-labeled fluoromethyl ketone peptide inhibitor (FLICA), using an excitation wavelength of $490 \mathrm{~nm}$ and an emission wavelength of $520 \mathrm{~nm}$ by a Jasco F 6300 spectrofluorimeter. Data represent the mean \pm SEM ( ${ }^{*} p<0.05$ vs control, $n=3$ ). doi:10.1371/journal.pone.0068224.g003

A
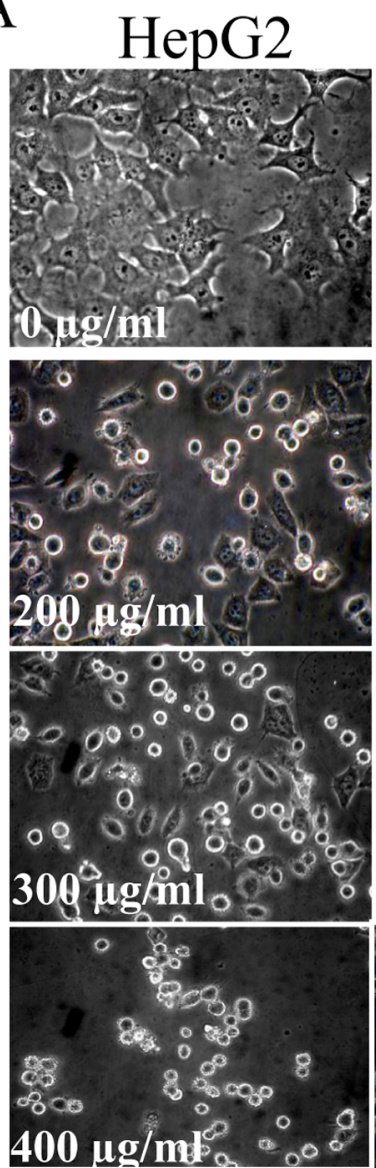

A549
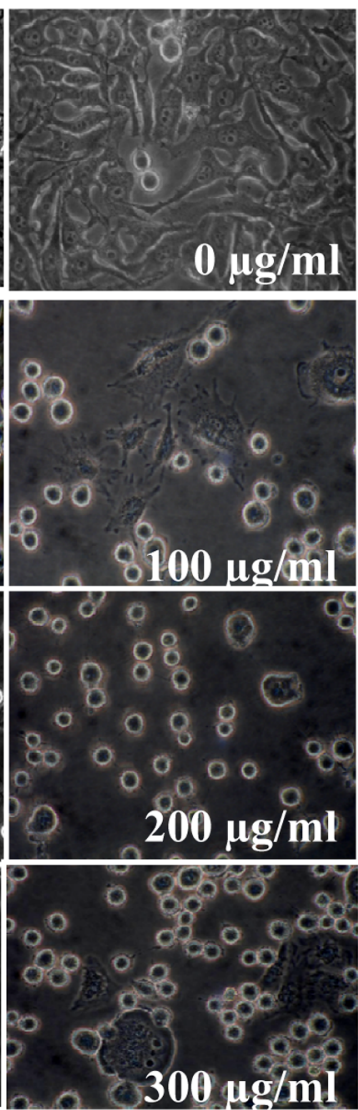

$\mathrm{B}$
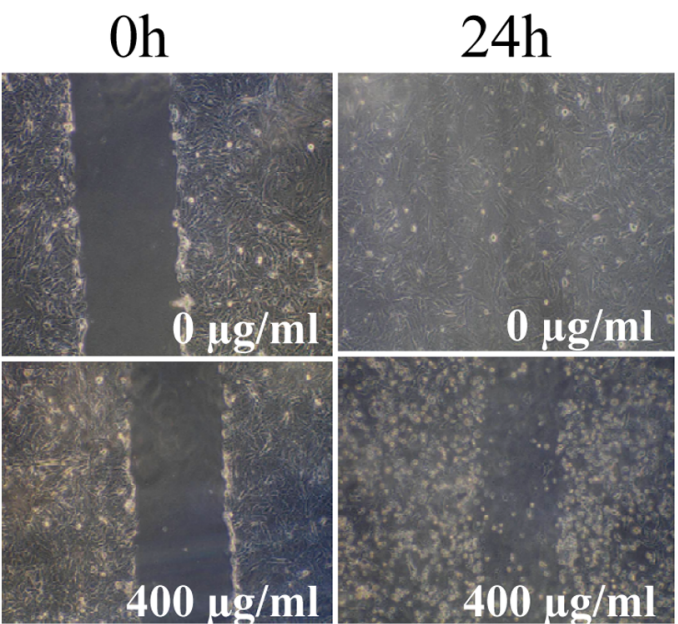

C
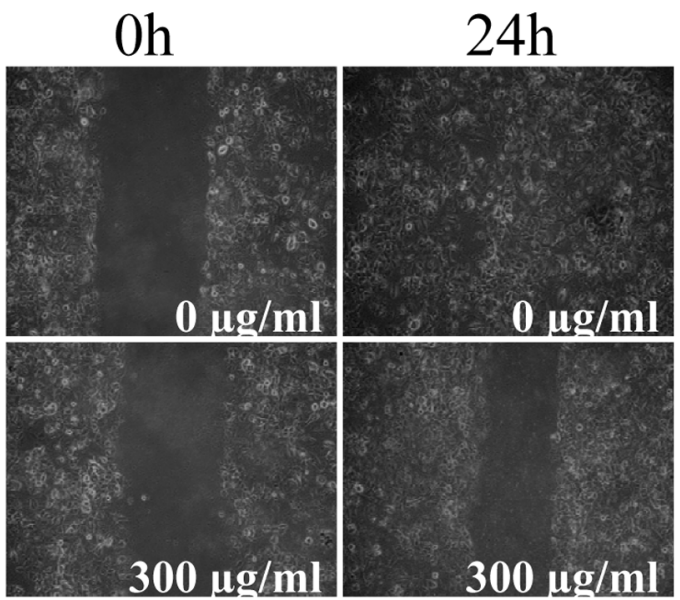

Figure 4. Alteration of cellular morphology and inhibition of cell migration in STE-treated HePG2 and A549 cells. (A) Contraction and shrinkage of cellular morphology of HepG2 and A549 cells in the presence of STE. (B) Inhibition of the migration of HepG2 cells in the absence and presence of $400 \mu \mathrm{g} / \mathrm{ml} \mathrm{STE} \mathrm{for} 24 \mathrm{~h}$. (C) Inhibition of the migration of A549 cells in the absence and presence of $300 \mu \mathrm{g} / \mathrm{ml} \mathrm{STE} \mathrm{for} 24 \mathrm{~h}$. doi:10.1371/journal.pone.0068224.g004 


\section{Cell Culture and Treatment}

Lung epithelial cells (A549), hepatic epithelial cells (HepG2), and mouse squamous epithelial cells (HCC7) were seeded onto plastic tissue culture flasks in DMEM medium containing $200 \mathrm{mg} / 100 \mathrm{ml} \mathrm{Na} 2 \mathrm{HCO}_{3}, 5 \%$ fetal bovine serum (FBS), $2 \mathrm{mM}$ L-glutamine, $100 \mathrm{IU}$ penicillin, and $100 \mathrm{mg} / \mathrm{ml}$ streptomycin, and incubated at $37^{\circ} \mathrm{C}$ in a $5 \% \mathrm{CO}_{2}$-air humidified atmosphere. Human blood peripheral mononuclear cells (PBMC) were immediately separated by density gradient centrifugation. Briefly, $5 \mathrm{~mL}$ blood was layered carefully over equalvolume of Histopaque 1077 and subjected to centrifugation for $30 \mathrm{~min}$ at $400 \times \mathrm{g}$. PBMC were collected from the buffy layer formed at the plasmaHistopaque 1077 interface and then suspended at a cell count of $1 \times 106$ cells $/ \mathrm{mL}$ in RPMI media. At $>80 \%$ confluence, cells were washed with PBS, and trypsinized to distribute $1 \times 10^{6}$ cells $/ \mathrm{ml}$ in $35 \mathrm{~mm}$ plates, which were then treated with different doses of STE for $24 \mathrm{~h}$. To determine the preventive measurement of NAC against STE-mediated toxicity the cells were pre-incubated with $500 \mu \mathrm{M}$ NAC for $12 \mathrm{~h}$, the media was then decanted and fresh media was added before adding the STE.

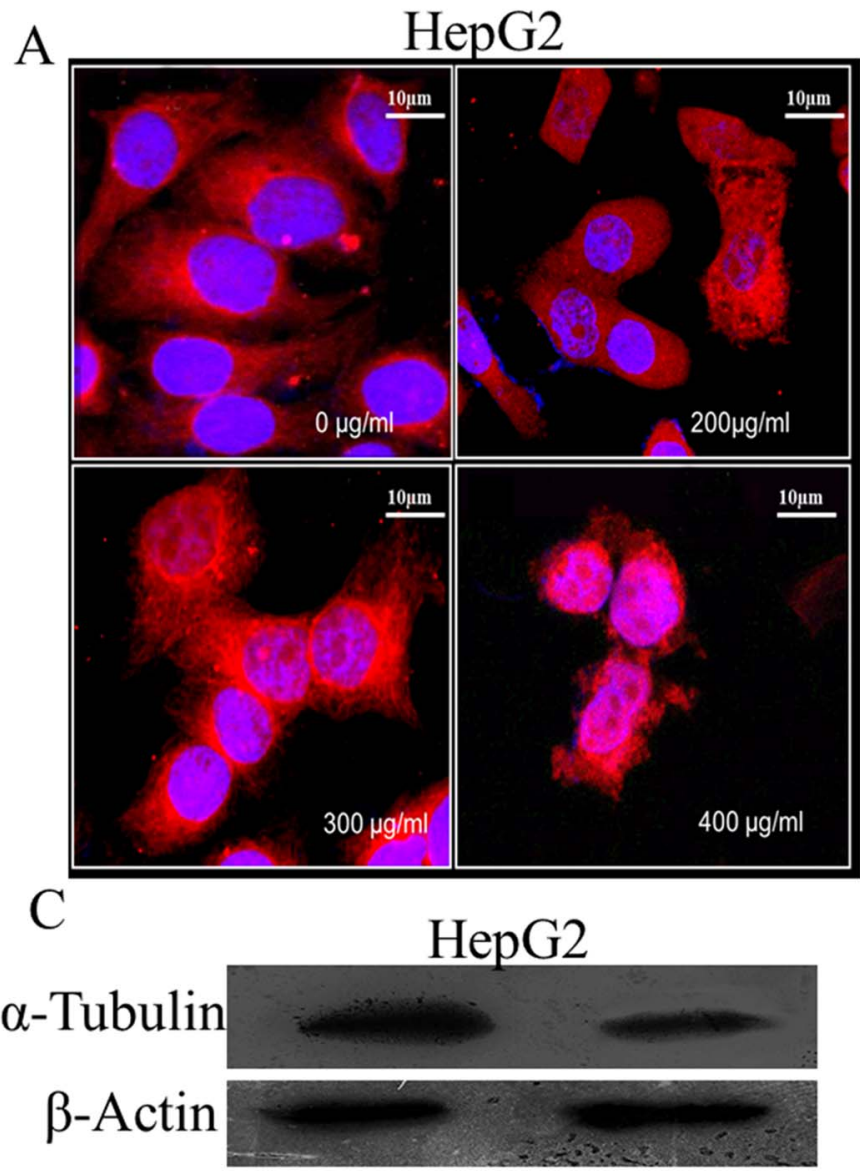

\section{Cell Viability Assay}

Cell viability was determined by MTT assay. Cultured mammalian cells were seeded in 96 -well plates at $1 \times 10^{4}$ cells per well, and was allowed to grow to $70 \% \sim 80 \%$ confluency, and treated with different doses of STE $(0-1000 \mu \mathrm{g} / \mathrm{ml})$ for $48 \mathrm{~h}$. Treated cells were incubated with MTT for $4 \mathrm{~h}$ at $37^{\circ} \mathrm{C}$, the medium was removed, and dye crystal formazan were solubilized in $150 \mu \mathrm{l}$ dimethyl sulphoxide (DMSO). Absorbance was measured at $570 \mathrm{~nm}$. Data were calculated as the percentage of inhibition by the following formula:

$$
\% \text { inhibitioin }=\left[1-\mathrm{A}_{\mathrm{t}} / \mathrm{A}_{\mathrm{s}}\right] \times 100 \%
$$

$A_{t}$ and $A_{s}$ indicated the absorbance of the test sample and solvent control, respectively [32].

\section{Determination of Apoptotic Population by Annexin V- FITC/PI Double Staining Method}

Cultured mammalian cells were treated with the respective IC50 doses of STE and apoptosis was determined by annexinVFITC/PI (propidium iodide) method. Varying STE doses were employed to HepG2 cells (0 to $400 \mu \mathrm{g} / \mathrm{ml}$ ), A549 cells (0 to
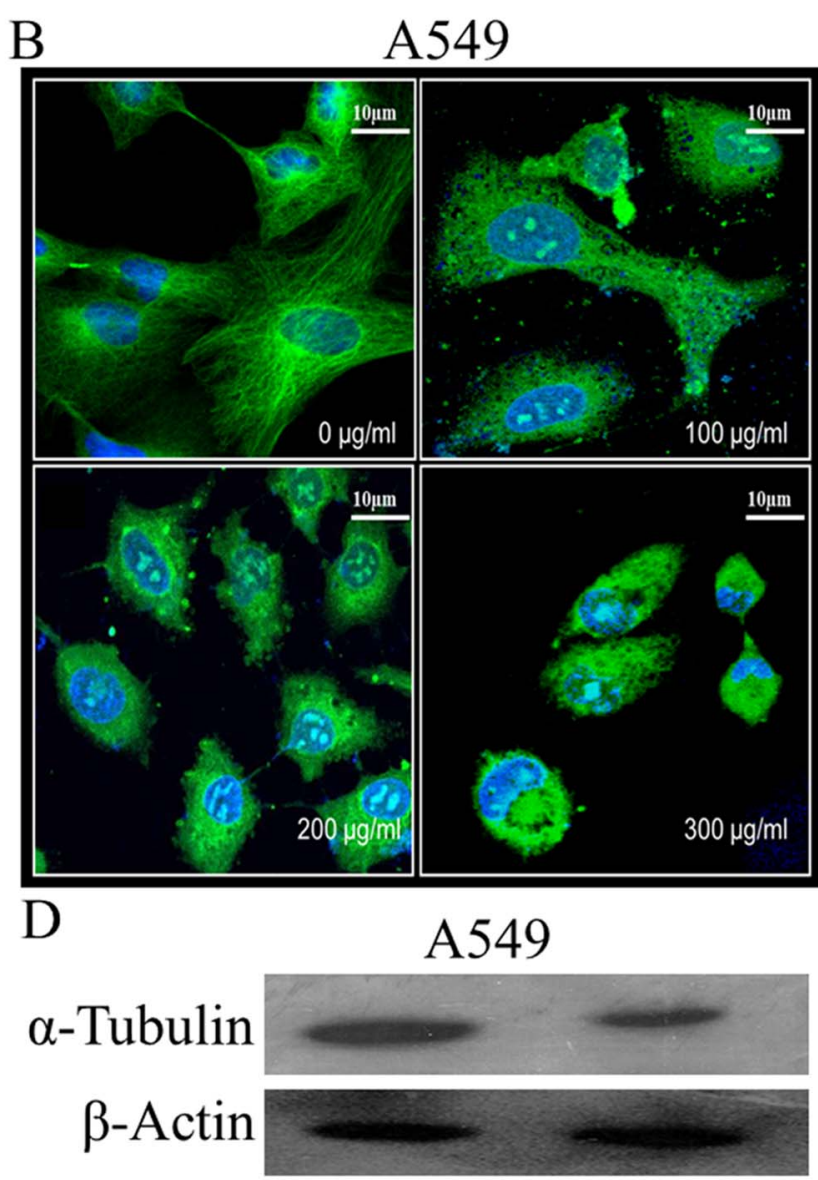

Figure 5. STE-mediated disruption and degradation of microtubules in HepG2 and A549 cells. Cultured HepG2 and A549 cells were treated with different doses of STE (0 to $400 \mu \mathrm{g} / \mathrm{ml}$ of STE). After $24 \mathrm{~h}$ treatment, cells were incubated with mouse monoclonal anti- $\alpha$-tubulin antibody and corresponding rhodamine tagged secondary antibody for HepG2 cells and mouse monoclonal anti- $\alpha$-tubulin antibody conjugated with FITC. Images of the untreated and STE-treated HepG2 cells (A) and A549 cells (B) were captured by a Ziess confocal microscope, LSM 510 meta. Western blot analysis against tubulin and actin proteins in HepG2 cells (C) and A549 cells (D) treated with STE (0-400 $\mu \mathrm{g} / \mathrm{ml})$ using mouse monoclonal anti- $\alpha$-tubulin and rabbit monoclonal anti- $\beta$-actin antibodies. Data are represented as best of three independent experiments. doi:10.1371/journal.pone.0068224.g005 


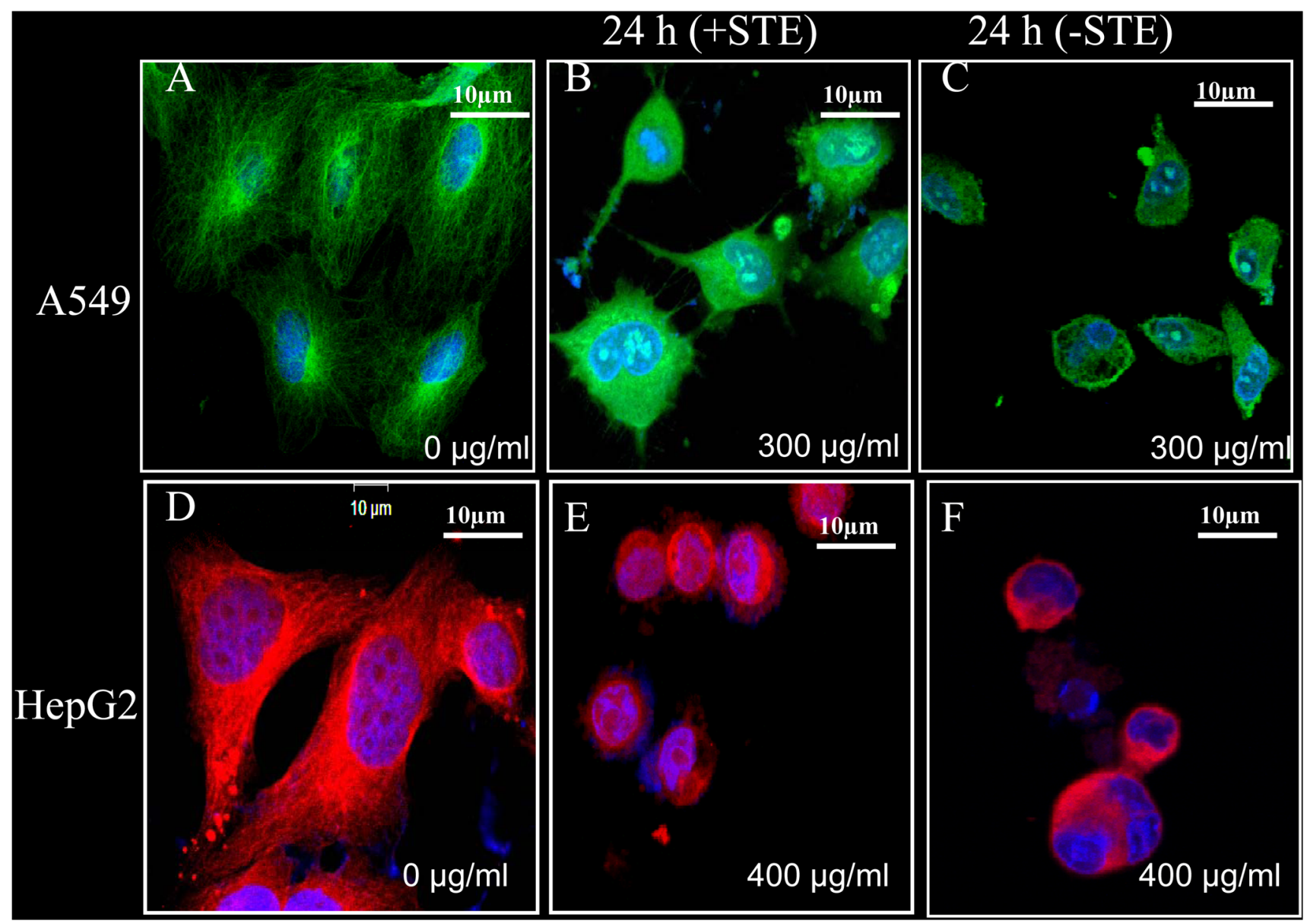

Figure 6. Irreversible disruption of the microtubule network in STE-treated A549 and HepG2 cells. Cultured A549 and HepG2 cells were treated with respective $\mathrm{IC}_{50}$ STE doses, with appropriate control sets (untreated cells). After $24 \mathrm{~h}$ of incubation, the media containing STE was replaced with fresh normal media without STE as discussed in methods. (A-C) Control and treated A549 cells were incubated with FITC-conjugated mouse monoclonal anti-tubulin antibody and images were captured by a Ziess confocal microscope LSM 510 meta. (D-F) Control and treated HepG2 cells were incubated with anti-tubulin (mouse monoclonal) antibody and corresponding rhodamine conjugated (red) secondary antibody and images were captured by a Ziess confocal microscope LSM 510 meta. The results represent the best of data collected from three experiments with similar results.

doi:10.1371/journal.pone.0068224.g006

$300 \mu \mathrm{g} / \mathrm{ml}$ ), HCG7 (0 to $400 \mu \mathrm{g} / \mathrm{ml}$ ) and PBMC (0 to $300 \mu \mathrm{g} / \mathrm{ml}$ ) for $48 \mathrm{~h}$. After decanting the media, live cells were incubated with annexinV-FITC in the binding buffer and then counterstained with propidium iodide (PI). Results were obtained on FACS calibur (Becton Dickinson) using Cell Quest software [33].

\section{Detection of Mitochondrial Membrane Potential (MMP)}

Cultured HepG2 and A549 were grown to a density of $1 \times 10^{6}$ cells $/ \mathrm{ml}$ and incubated $24 \mathrm{~h}$ in presence STE of different doses $(0-$ $300 \mu \mathrm{g} / \mathrm{ml}$ for A549 and $0-400 \mu \mathrm{g} / \mathrm{ml}$ for HepG2). Changes in the mitochondrial membrane potential (MMP) were scrutinized with the fluorescent tagged rhodamine 123 by FACS calibur (Becton Dickinson) using Cell Quest software [32].

\section{Measurement of Caspase-3 Activity}

Caspase-3 activities were assayed in both A549 and HepG2 cells by following the method described in [18]. In this assay, FAMDEVD-FMK, a cell permeable carboxyfluorescein-labeled fluoromethyl ketone peptide inhibitor (FLICA) of Caspase-3 was used. Cultured HepG2 and A549 were exposed to different STE doses $(0-300 \mu \mathrm{g} / \mathrm{ml}$ for $\mathrm{A} 549$ and $0-400 \mu \mathrm{g} / \mathrm{ml}$ for HepG2), for $24 \mathrm{~h}$.
The green fluorescence of FLICA in the A549 and HepG2 cells was evaluated by fluorescence spectroscopy by monitoring the fluorescence obtained at $520 \mathrm{~nm}$.

\section{Confocal Microscopy for Cellular Microtubule Structure}

Cultured HepG2 and A549 cells were grown to a density $1 \times 10^{6}$ cells $/ \mathrm{ml}$ and incubated with different doses of STE $(0-400 \mu \mathrm{g} / \mathrm{ml})$ for $24 \mathrm{~h}$. After treatment cells were fixed with $2 \%$ paraformaldehyde and processed further following the published protocol [18]. HepG2 cells were then incubated with mouse monoclonal antitubulin antibody (1:100), followed by rhodamine conjugated secondary antibody (1:100), while A549 cells were incubated with FITC-conjugated mouse monoclonal anti-tubulin antibody (1:100). Images of the cellular microtubules were taken by Ziess confocal microscope (LSM 510 Meta).

\section{Western Blotting of Tubulin and Actin Following STE} Treatment

Cultured HepG2 and A549 cells were grown to a density $1 \times 10^{6}$ cells $/ \mathrm{ml}$ and treated with different doses of STE $(0-300 \mu \mathrm{g} / \mathrm{ml}$ for A549 and $0-400 \mu \mathrm{g} / \mathrm{ml}$ for HepG2) to estimate the intracellular 

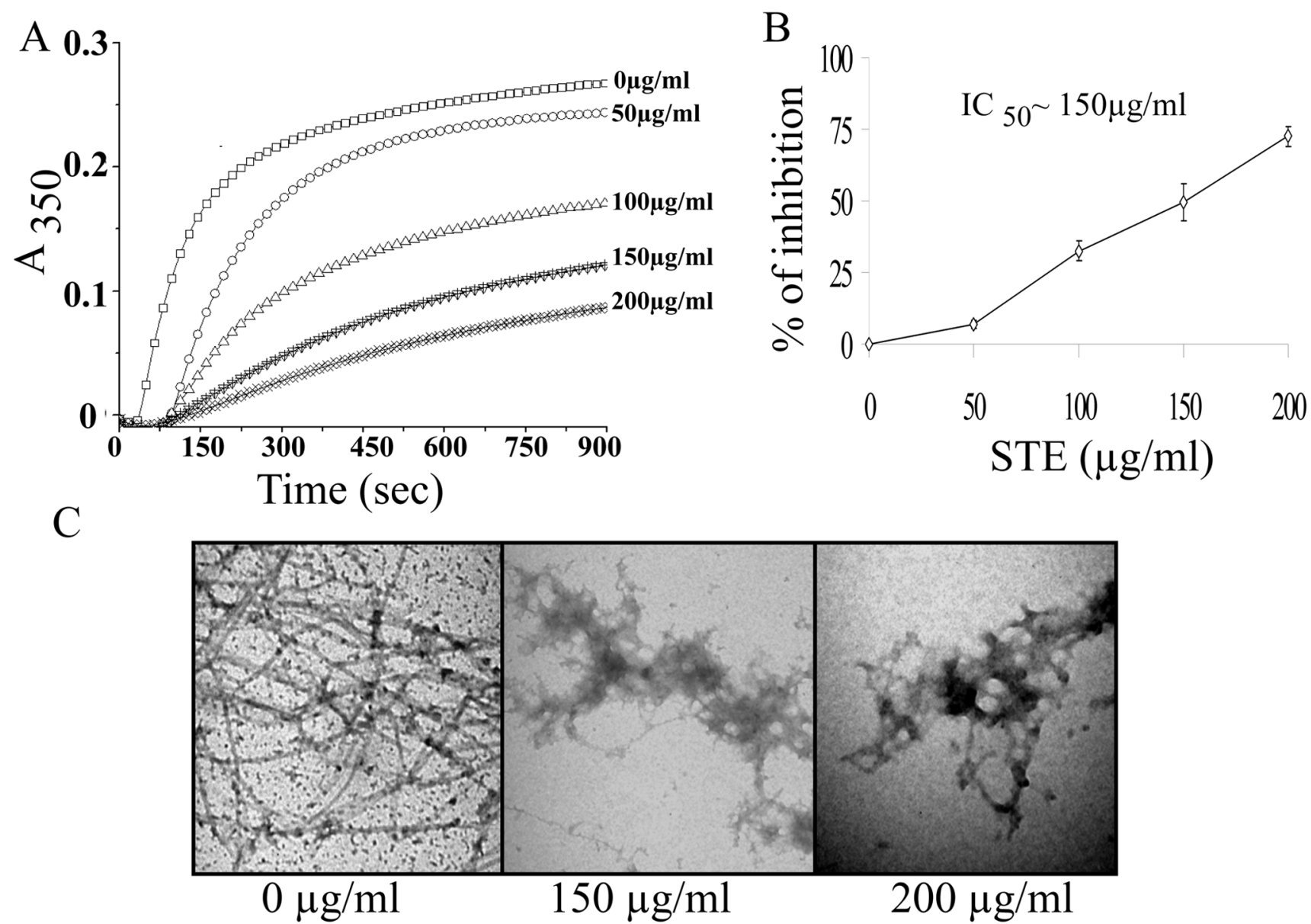

Figure 7. Inhibition of the assembly of purified tubulin by STE. (A) Tubulin assembly study. Tubulin (12 $\mu$ M) was polymerized separately in the presence of $(0-200 \mu \mathrm{g} / \mathrm{ml}) \mathrm{STE}$ at $37^{\circ} \mathrm{C}$. The progress of tubulin assembly was monitored spectrophotometrically at $350 \mathrm{~nm}$. (B) A plot of percentage of polymerization inhibition against dose of STE. Data represent the mean \pm SEM $(p<0.05$ vs control, $n=3)$. (C) Aggregation of microtubule protofilaments in the presence of STE as observed by a transmission electron microscopy. Tubulin (12 $\mu \mathrm{M})$ was polymerized separately in the presence of different STE doses $(0-200 \mu \mathrm{g} / \mathrm{ml})$, and the images were taken at 20000X magnification. The bar represents $500 \mathrm{~nm}$. The results represent the best of data collected from three experiments with similar results.

doi:10.1371/journal.pone.0068224.g007

effect of STE on two well known structural proteins tubulin and $\beta$ actin. $50 \mu \mathrm{g}$ of total protein was loaded in each well during SDSPAGE, and then western blot was carried on. Mouse monoclonal anti- $\alpha$-tubulin antibody (1:5000 dilution, obtained from Sigma, USA) and rabbit monoclonal anti- $\beta$-actin (1:1000 dilution, obtained from Sigma, USA) were used as primary antibodies, and HRP-tagged anti-mouse IgG (raised in goat) and HRP-tagged anti-rabbit IgG (raised in goat) were as secondary antibodies (1:10000 dillution, purchased from Santacruz, USA).

\section{Purification of Tubulin from Goat Brain}

Tubulin was isolated from goat brain by two cycles of temperature-dependent assembly and disassembly in PEM buffer (50 mM PIPES, $1 \mathrm{mM}$ EGTA, and $0.5 \mathrm{mM} \mathrm{MgCl}_{2}$ at $\mathrm{pH} 6.9$ ), in the presence of $1 \mathrm{mM}$ GTP, followed by two more cycles in $1 \mathrm{M}$ glutamate buffer [34]. The purified tubulin, free of MAPs was checked by $8 \%$ SDS-PAGE. Aliquots were flash-frozen in liquid nitrogen and stored at $-70^{\circ} \mathrm{C}$. The protein concentration was estimated by the method of Bradford [35] using bovine serum albumin as the standard.
Inhibition of Purified Tubulin Assembly In Cell Free System by STE

Tubulin $(12 \mu \mathrm{M})$ was mixed with different doses of STE in polymerization buffer $1 \mathrm{mM} \mathrm{MgSO} 4,1 \mathrm{mM}$ EGTA, $1 \mathrm{mM}$ GTP, $1.0 \mathrm{M}$ monosodium glutamate, $\mathrm{pH} 6.8$ ), and the assembly reaction was initiated by incubating the sample at $37^{\circ} \mathrm{C}$ in the presence of different doses of STE $(0-200 \mu \mathrm{g} / \mathrm{ml})$. The rate and extent of the polymerization reaction were monitored by light scattering at $350 \mathrm{~nm}$.

\section{Transmission Electron Microscopy (TEM) Study for Detecting Microtubule Polymers}

Samples for TEM were prepared following the published protocol [17]. Tubulin $(1.2 \mathrm{mg} / \mathrm{ml})$ was polymerized at $37^{\circ} \mathrm{C}$ in the absence and presence of different doses of STE, for $1 \mathrm{~h}$ in a $300 \mu \mathrm{l}$ mixture. Microtubules were then fixed in $0.5 \%$ prewarmed glutaraldehyde for $5 \mathrm{~min}$. Each sample $(10 \mu \mathrm{l})$ was loaded in carbon-coated electron microscope grids (300-mesh) for $20 \mathrm{~s}$ and blotted dry. The grids were subsequently negatively stained with $1 \%$ uranyl acetate and air-dried. The samples were viewed using a Philips Fei Technai G212 electron microscope. Images were taken at $20000 \times$ magnifications. 
A

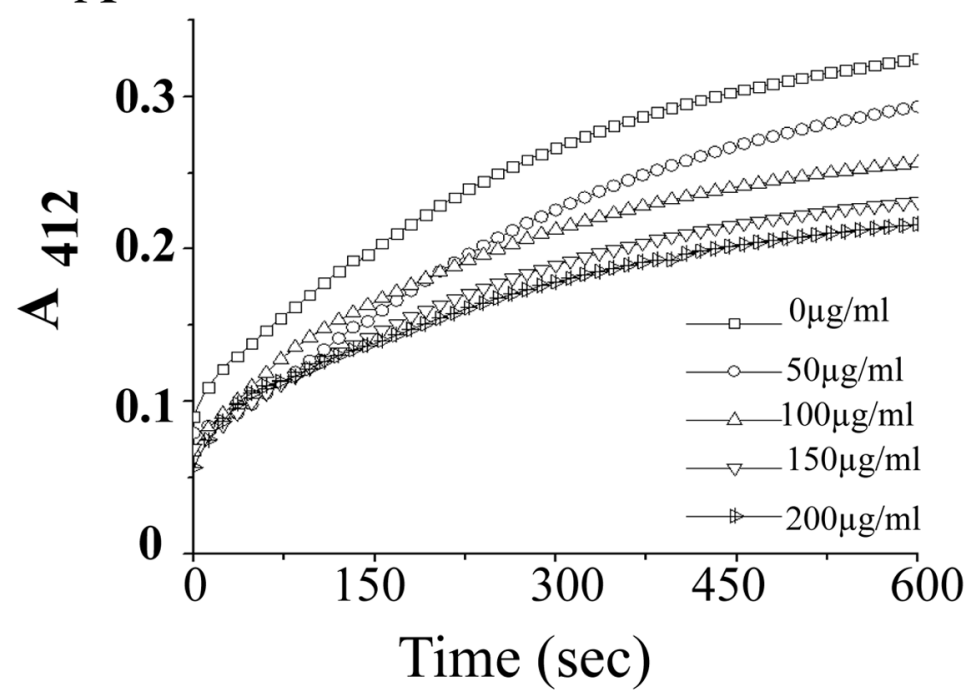

B

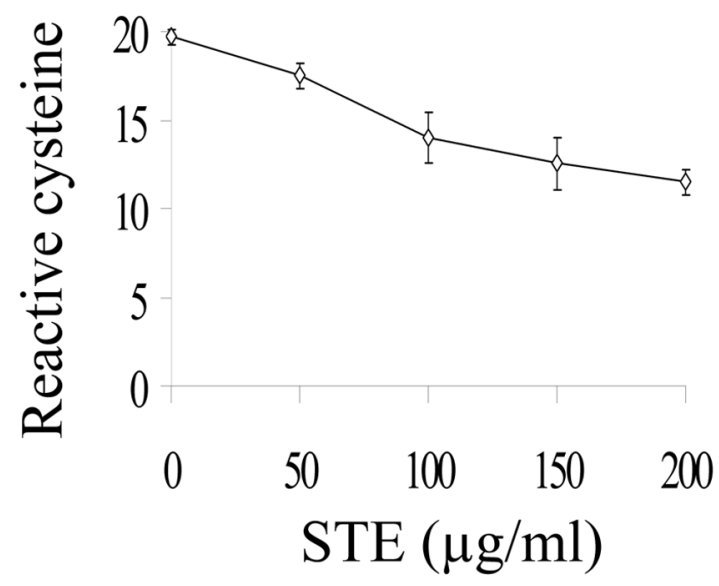

Figure 8. Estimation of reactive cysteine residues of tubulin by DTNB reaction. Tubulin $(10 \mu \mathrm{M})$ was separately treated with $(0-200) \mu \mathrm{g} /$ $\mathrm{ml} \mathrm{STE} \mathrm{for} 1 \mathrm{~h}$. (A) Samples are diluted for normalization of protein concentration to $1 \mu \mathrm{M}$ and cysteine residues were estimated by reaction with DTNB as described in the 'Materials and Methods'. (B) A plot of total available reactive cysteine residues of tubulin against concentration of STE. Data represent the mean \pm SEM $(p<0.05$ vs control, $n=3)$. doi:10.1371/journal.pone.0068224.g008

\section{Measurement of Reactive Cysteine Residues of Tubulin by DTNB Assay}

Formation of thio-nitrobenzoate anion (TNB) by DTNB reaction with the free sulfhydryl groups was measured by monitoring absorbance at $412 \mathrm{~nm}$, and number of reactive cysteine residues were calculated using $\varepsilon_{412}=13,600 \mathrm{M}^{-1} \mathrm{~cm}^{-1}$ for TNB [36]. Tubulin $(10 \mu \mathrm{M})$ in $50 \mathrm{mM}$ PEM buffer, was incubated with different doses of STE $(0 \mu \mathrm{g} / \mathrm{ml} 200 \mu \mathrm{g} / \mathrm{ml})$ in $200 \mu \mathrm{L}$ final volume, at $37^{\circ} \mathrm{C}$ for $15 \mathrm{~min}$. After the incubation, tubulin was diluted 10 -fold to make the final tubulin concentration $1 \mu \mathrm{M}$, and the numbers of reactive cysteine were estimated spectrophotometrically by DTNB kinetics.

\section{Statistical Analysis of Data}

Data are presented as the mean of at least three independent experiments along with standard error of the mean (SEM). Statistical analysis of data was done by one-way analysis of variance (ANOVA), with Student-Newman-Keul test by using Sigma plot 11.0. The $\mathrm{p}$ value $<0.05$ was considered to be statistically significant.

\section{Results}

Loss of Viability of Mammalian Cell Lines upon Treatment with STE

Cell viability experiments (MTT assay) were performed using human liver epithelial cells HepG2, lung epithelial cells A549, mouse squamous epithelial cells HCG7 and human peripheral blood mononuclear cells PBMC in the presence of different doses of STE after incubation for $48 \mathrm{~h}$ (Fig. 1). A dose-dependent loss of viability was observed, when the cells were treated with STE and the respective $\mathrm{IC}_{50}$ observed were around $400 \mu \mathrm{g} / \mathrm{ml}$ for HepG2 cells, $300 \mu \mathrm{g} / \mathrm{ml}$ for A549 cells, $430 \mu \mathrm{g} / \mathrm{ml}$ for HCC7 cells and $300 \mu \mathrm{g} / \mathrm{ml}$ for PBMC.
Induction of Apoptosis in Mammalian Cell Lines by STE

Smokeless tobacco extract induced apoptosis in mammalian cells were monitored flowcytometrically by FITC-annexin-V/ propidium iodide (PI) double staining assay. A significant amount of annexin $\mathrm{V}$ positive (early apoptotic) cells were observed, when the cells were treated with STE (Fig. 2A). At the respective $\mathrm{IC}_{50}$ dose, apoptotic population in STE-treated cells increased significantly. About $28 \%$ of STE-treated HepG2 cells were found to be apoptotic where as in A549 and HCG7 cells, the apoptotic population was found to be $34 \%$ and $37 \%$, respectively. When PBMC were treated with STE, about $43 \%$ of the cells were found to be apoptotic. These results indicated that exposure to STE a triggers cell death and apoptosis in the cultured mammalian cells.

Loss of Mitochondrial Membrane Potential (MMP) and Activation of Caspase-3 in the STE- Treated HepG2 and A549 Cells

To examine the involvement of mitochondria in STE-induced apoptosis, alterations in the mitochondrial membrane potential (MMP) were monitored with the fluorescent probe rhodamine 123 by FACS. A gradual decrease in the rhodamine florescence intensity was observed when HepG2 and A549 cells were treated with different STE doses $(0-400 \mu \mathrm{g} / \mathrm{ml})$. For STE-treated HepG2 cells, rhodamine-mean fluorescence intensity (MFI) was found to be decreased from 823 in the untreated cells, to 640 at $300 \mu \mathrm{g} / \mathrm{ml}$ STE dose and 532 at $400 \mu \mathrm{g} / \mathrm{ml}$ STE dose respectively (Fig. 2B). Similarly for A549 cells STE- treatment resulted in the decrease of MFI from 890 in the untreated cells to 750 at $200 \mu \mathrm{g} / \mathrm{ml} \mathrm{STE}$ dose and 460 at $300 \mu \mathrm{g} / \mathrm{ml}$ STE dose respectively (Fig. 2C).

Activation of the caspase- 3 is an obvious downstream event in the mitochondrial dependent apoptotic pathway. Activation of the caspase- 3 in control and STE-treated HepG2 and A549 cells were assessed by both western blot against pro-caspase- 3 and determination of caspase-3 activity by fluorometric analysis (Fig. 3). Expression levels of pro-caspase-3 were reduced significantly in both HepG2 and A549 cells when treated with the respective $\mathrm{IC}_{50}$ 

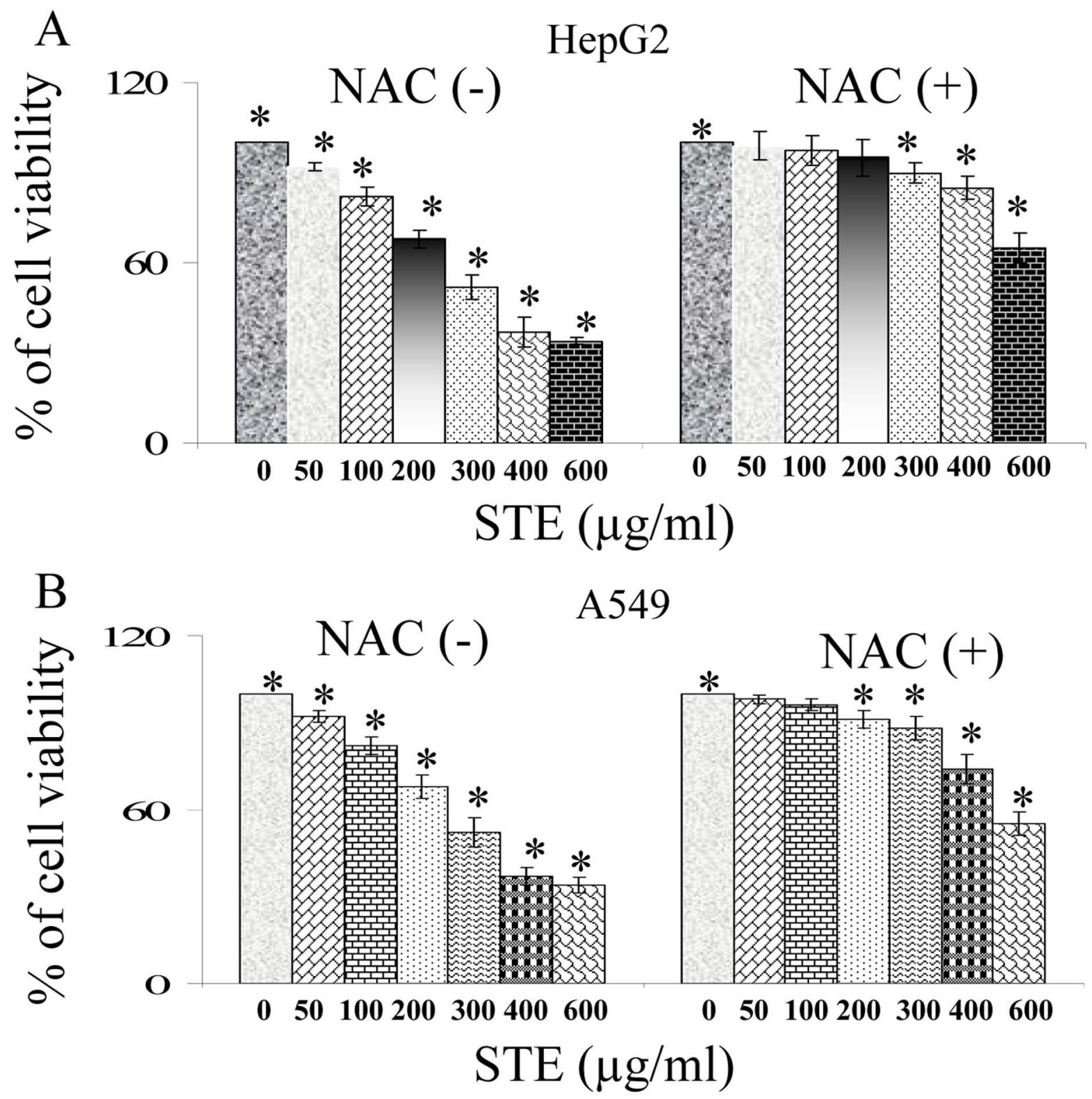

Figure 9. Attenuation of STE induced cytotoxicity in both HepG2 and A549 cells by $\mathbf{N}$-acetyl cysteine (NAC). Determination of the viability of HepG2 and A549 cells treated with STE $(0-600 \mu \mathrm{g} / \mathrm{ml})$ alone or incubated with $500 \mu \mathrm{M}$ NAC prior STE-treatment. Viability for (A) HepG2 and (B) A549 cells was determined by MTT assay. Data are represented as the mean \pm SEM ( ${ }^{*} \mathrm{P}<0.05$ vs control or STE untreated $+\mathrm{NAC}$ treated cells), where $\mathrm{n}=4$.

doi:10.1371/journal.pone.0068224.g009

dose of STE, as confirmed by western blot (Fig. 3A,G). Activation of caspase-3 was confirmed by monitoring the fluorescence obtained at $520 \mathrm{~nm}$, upon excitation at $490 \mathrm{~nm}$ (Fig. 3B,D). When HepG2 cells were treated with STE around 1.5 \pm 0.1 -fold increase in caspase-3 activity was observed at $300 \mu \mathrm{g} / \mathrm{ml}$ STE dose and on treatment with $400 \mu \mathrm{g} / \mathrm{ml} \mathrm{STE}$, caspase- 3 activity was increased by $4.4 \pm 0.20$ fold (Fig. 3B). A dose-dependent increase in caspase- 3 activity was also observed, when A549 cells were treated with STE. Around 2 \pm 0.4 -fold increase in the caspase- 3 activity was observed at $200 \mu \mathrm{g} / \mathrm{ml}$ STE dose and on treatment with $300 \mu \mathrm{g} / \mathrm{ml}$ STE, caspase-3 activity was increased by $5.0 \pm 0.2$-fold (Fig. 3D).
Alteration in Cellular Morphology and Inhibition of Migratory Properties of STE-Treated HepG2 and A549 Cells

The normal morphology of the HepG2 and A549 cells was found to be altered by STE in a dose-dependent manner. Cultured HepG2 and A549 cells were treated with various STE doses (0$400 \mu \mathrm{g} / \mathrm{ml}$ ), incubated for and $24 \mathrm{~h}$, and phase contrast images of the cells were captured by the Olympus inverted microscope. The untreated cells have regular cellular morphologies, but aberrations in the morphology were observed after the STE treatment, in a dose-dependent fashion (Fig. 4A). With the gradual increase in STE dose, significant shrinkage and contraction of cytoplasmic materials were observed in both HepG2 and A549 cells accompanied by the complete loss of cellular integrity. 


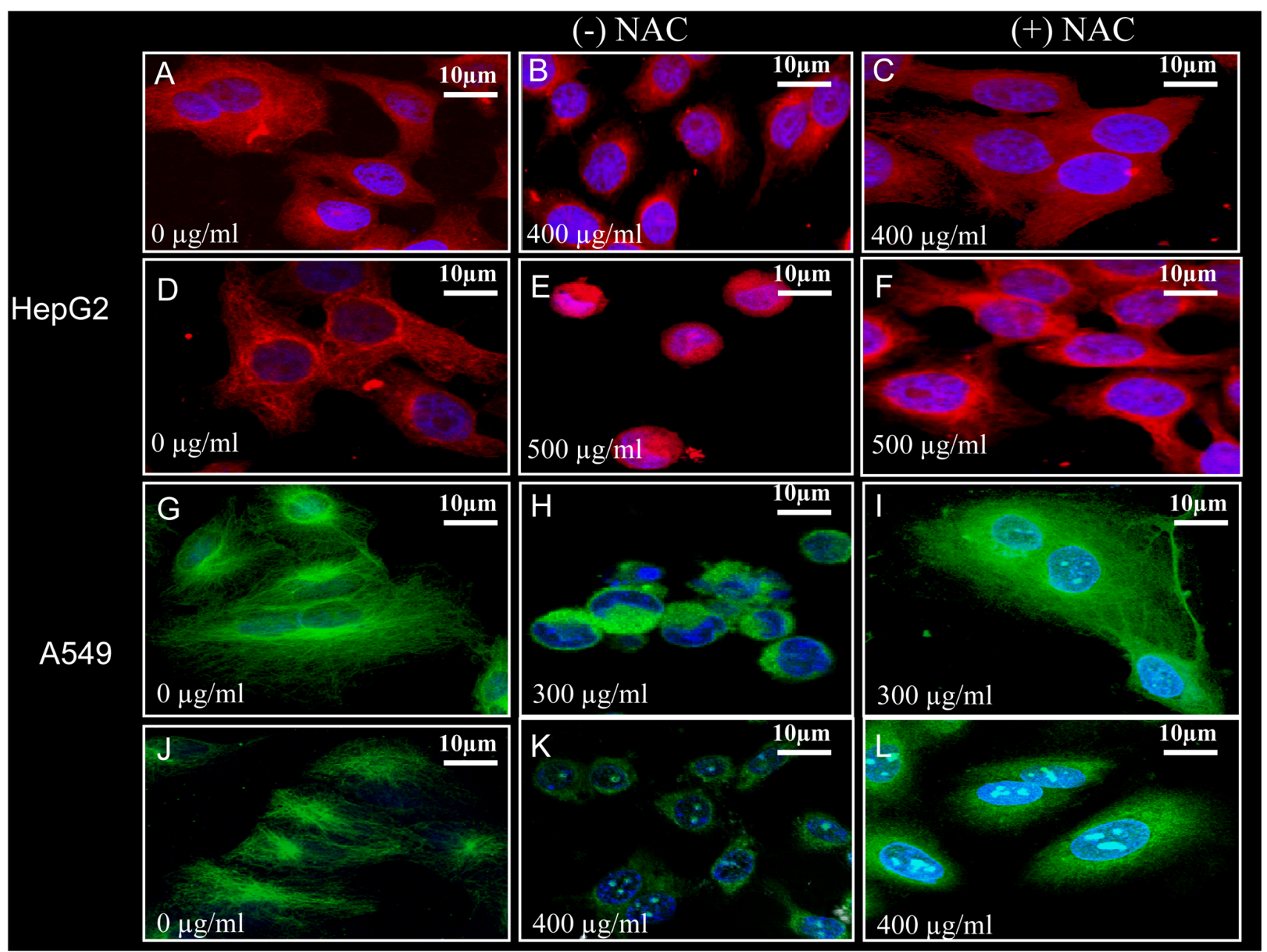

Figure 10. NAC mediated prevention of STE-induced damage of microtubule structure in HepG2 and A549 cells. Microtubules of the HepG2 and A549 cells were probed with mouse monoclonal rhodamine or FITC tagged anti- $\alpha$-tubulin antibody as before and images were taken by confocal microscope for STE-untreated samples $(A, D, J, G)$, STE-treated samples $(B, E, H, K)$ and NAC-pretreated-then STE-treated samples $(C, F, I, L)$. Details of the experiments are described in 'Methods' section. The results represent the best of data collected from three experiments with similar results. doi:10.1371/journal.pone.0068224.g010

Migratory activities of HepG2 and A549 cells in the absence and presence of STE were observed by the wound-healing assay. Confluent monolayers of cultured HepG2 and A549 were scraped with a plastic pipet tip to create a wound, and then incubated with the respective $\mathrm{IC}_{50}$ dose $24 \mathrm{~h}$ (Fig. 4B,C). The untreated cells were found to heal the wound after $24 \mathrm{~h}$ of incubation, but in the presence of STE, the treated cells completely failed to migrate. This observation clearly indicated that STE inhibited the migratory properties of the mammalian cells.

\section{Irreversible Disruption of Microtubule Network in STE-}

Treated HepG2 and A549 Cells, Followed by the

\section{Degradation of Total Tubulin}

Since microtubules play important roles in the maintenance of cellular architecture and migratory activities of mammalian cells, we investigated the status of the cellular microtubules in the STEtreated HepG2 and A549 cells. The organization of microtubule structure in the absence and presence of STE were examined by confocal microscopy (Fig. 5A,B). In case of untreated cells, regular microtubule structures were observed, but with the increasing STE concentrations microtubule disruption took place in both the cell lines. In the untreated HepG2 cells fibrous microtubule structures were observed under the confocal microscope, but at relatively lower STE doses e.g. $200 \mu \mathrm{g} / \mathrm{ml}$ and $300 \mu \mathrm{g} / \mathrm{ml}\left(<\mathrm{IC}_{50}\right.$ dose $)$ microtubule disruptions were very prominent. Further at $400 \mu \mathrm{g} /$ $\mathrm{ml}$ STE concentration microtubule disruption was aggravated (Fig. 5A). Similarly for A549 cells aberration of the normal microtubule structure was initiated at the dose of $100 \mu \mathrm{g} / \mathrm{ml}$, and at the doses of $200 \mu \mathrm{g} / \mathrm{ml}$ and $300 \mu \mathrm{g} / \mathrm{ml}$ of STE, microtubule structures were totally disrupted (Fig. 5B).

It was reported that chemical modification of tubulin in cells resulted in the proteosomal degradation of the protein [30]. Degradation of tubulin in STE-treated HepG2 cells was observed by western blotting (Fig. 5G). Cultured HepG2 cells, when incubated for $24 \mathrm{~h}$ in the presence of $400 \mu \mathrm{g} / \mathrm{ml} \mathrm{STE}\left(\mathrm{IC}_{50}\right.$ dose), resulted in tubulin degradation. Under similar experimental conditions, status of another major cytoskeletal protein actin was checked, and degradation of actin was not observed in STEtreated HepG2 cells. Similar result was obtained when A549 cells were treated with STE $(400 \mu \mathrm{g} / \mathrm{ml})$ and western blots for tubulin and actin were performed (Fig. 5D). These results indicated that STE specifically interacts with tubulin in cultured mammalian cells. 
Further investigations revealed that disruption of microtubule network in STE-treated HepG2 and A549 cells occurred in an irreversible manner. Cells were treated with the respective $\mathrm{IC}_{50}$ dose of STE for $24 \mathrm{~h}$, and the old medium was then replaced with fresh medium without STE and again incubated for $24 \mathrm{~h}$. Confocal images of microtubules in untreated (Fig. 6A,D) and treated (Fig. 6C,F) cells revealed that the damaged microtubules in the STE-treated cells failed to recover.

These results clearly indicated that the disruption of the interphase microtubules in the STE treated cultured cell lines were responsible for the aberration of cellular morphology and inhibition of migratory properties.

\section{Inhibition of Purified Tubulin Polymerization by STE}

As smokeless tobacco disrupted of microtubule network of HepG2 and A549 cells, we like to know whether STE inhibits polymerization of purified tubulin into microtubules. Inhibition of microtubule assembly by STE was studied in cell-free system by light scattering experiment by monitoring absorbance at $350 \mathrm{~nm}$. Purified tubulin $(12 \mu \mathrm{M})$ was polymerized in the absence or presence of different doses of STE as described in the 'Materials and Methods'. The STE was found to inhibit the rate and extent of tubulin polymerization in a dose-dependent manner (Fig. 7A). The percentage inhibition of microtubule polymerization was calculated using the steady-state absorbance readings in the absence and presence of different doses of STE (Fig. 7B). Around $54 \%$ inhibition of tubulin polymerization was occurred at STE dose of $150 \mu \mathrm{g} / \mathrm{ml}$. Again in a $200 \mu \mathrm{g} / \mathrm{ml}$ dose of STE, $70 \%$ inhibition of tubulin polymerization was observed.

This result was further confirmed by transmission electron microscopy study (Fig. 7C). In the untreated set, tubulin dimers polymerize efficiently to form the polymeric microtubules as evident from the micrograph image. But in the presence of STE doses of $150 \mu \mathrm{g} / \mathrm{ml}$ and $200 \mu \mathrm{g} / \mathrm{ml}$, tubulin aggregates were observed instead of the polymeric mass. These results clearly indicate that STE is interfering with the polymerization properties of tubulin dimers.

\section{Loss of Reactive Cysteine Residues of Tubulin in the Presence of STE}

The tubulin dimer has 20 cysteine residues that play important role in folding, and polymerization of tubulin $[37,38]$ and oxidation or modification of these sulfhydril groups is usually accompanied with the loss of polymerization activity [26,34]. Among the 20 residues, 18-20 are available for reaction with DTNB [33], and we estimated number of cysteine residues in the absence and presence of STE by DTNB reaction (details in 'Methods'). A linear decrease in the reactive cysteine residues of tubulin was observed with the gradual increase in STE doses from $0 \mu \mathrm{g} / \mathrm{ml}$ to $200 \mu \mathrm{g} / \mathrm{ml}$ (Fig. 8A,B). In the presence of $150 \mu \mathrm{g} / \mathrm{ml}$ STE, a loss of around 8 cysteine residues was observed as compared with the control.

\section{N-Acetyl Cysteine (NAC) Mediated Protection of A549 and HepG2 Cells Against STE Mediated Cytotoxicity and Microtubule Disruption}

$\mathrm{N}$-acetyl cysteine (NAC) is well known and clinically used antioxidant which increases cell's intrinsic anti-oxidant pool. In the current experimental theme, it has been utilized as a protective shield against STE induced cytotoxicity. When HepG2 cells were exposed to STE, the $\mathrm{IC}_{50}$ was around $400 \mu \mathrm{g} / \mathrm{ml}$ but on pretreatment with $500 \mu \mathrm{M} \mathrm{NAC}$, the cell viability was significantly restored to more than $85 \%$ (Fig. 9A). Similarly at STE dose of
$300 \mu \mathrm{g} / \mathrm{ml}$, A549 cells showed $50 \%$ viability but upon pretreatment with $500 \mu \mathrm{M}$ NAC, cell viability was increased to $88 \%$ (Fig. 9B).

In our previous experiments, we have shown that exposure of HepG2 and A549 cells to STE resulted in the disruption of cellular microtubules. To find out whether NAC acts as a protective parameter, we pre-incubated both HepG2 and A549 cells with $500 \mu \mathrm{M}$ of NAC for $12 \mathrm{~h}$, before STE treatment (400 and $500 \mu \mathrm{g} / \mathrm{ml}$ ). Without pre-treatment with NAC, microtubules were disrupted in the presence of STE (Fig. 10B,E for HepG2 cells and Fig. $10 \mathrm{H}, \mathrm{K}$ for A549 cells). Very interestingly we observed that NAC pre-treatment is inhibiting STE-induced microtubule disruption in both HepG2 (Fig. 10C,F) and A549 cells (Fig. 10I,L).

\section{Discussion}

Usage of the smokeless tobacco as the "spit tobacco" or "chewing tobacco" in forms of moist smokeless tobacco (MST) or commercially available "Ghutkha", has become a very common habit worldwide [1-3]. Long-term exposure to ST leads to the formation of oral mucosal lesions and tissue injury [1] but the extent of damage was found to be systemic and contributory to the development of cardiovascular disorders [5], and inflammatory responses in lung and hepatic tissues [31]. Smokeless tobacco extract was also known to induce apoptosis and cellular damage [12-16], but the precise mechanism is yet unclear. In our previous reports we have demonstrated that microtubules, one of the major cytoskeleton proteins participating in diverse cellular functions, may act as a potential target for tobacco smoke and smokecomponents and disruption of the cellular microtubule network leads to apoptosis [17-19]. Thus in the present study we have investigated the role tubulin-microtubule in STE-mediated cytotoxicity and apoptosis in mammalian cells.

Application of STE on mammalian cells shows a concentrationdependent decrease in the cell viability as evident from the MTT assay (Fig. 1). Furthermore it was observed that STE-treatment resulted in the induction apoptosis in the treated cell lines and the mitochondrial dependent activation of caspase- 3 was also observed (Fig. 2,3). We also observed that induction of apoptosis due to STE-treatment is associated with the loss of cellular architecture and migratory properties of the treated cells (Fig. 4) and further studies revealed that STE-treatment resulted in a gradual perturbation and degradation of the cellular microtubule organization in both HepG2 and A549 cells (Fig. 5) and the effect is dosedependent and irreversible (Fig. 6). In previous reports we have shown that cigarette smoke extract or smoke component like PBQ selectively targets cellular microtubules but the other house keeping proteins like glyceraldehyde-3-phosphate and $\beta$-actin remain unaffected $[17,18]$. Similar results were obtained for both HepG2 and A549 cells followed by STE-treatment. It was observed that in both the cell lines, STE-treatment resulted in a drastic decrease in tubulin levels whereas levels of actin remained unaltered. Polymerizing property of the purified tubulin was also inhibited by STE in a dose-dependent fashion (Fig. 7) and this is accompanied by the loss of reactive cysteine residues of tubulin (Fig. 8).

The reactive cysteine residues of tubulin are known to regulate important structural and functional properties of the protein such as folding, and polymerization $[37,38]$ and any kind of chemical modification of these reactive cysteine residues may result in the proteosomal degradation of tubulin [30]. Thus it may be concluded that tubulin serves as a direct target for STEcomponents, which may oxidize/modify tubulin sulfhydrils and result in the intracellular degradation of the protein. 
In our previous report we have shown that, $\mathrm{PBQ}$ a cytotoxic quinone, present in cigarette smoke and diesel smoke, targets the sulfhydrils of tubulin and induces apoptosis in mammalian cells [18]. Application of the thiolic antioxidant NAG not only reversed PBQ-mediated cytotoxicity, but also conferred protection to the cellular microtubules and purified tubulin against PBQ-mediated damage [18]. Henceforth we have hypothesized that application of NAC improves the intracellular thiol pool directly or indirectly, which in turn inhibits PBQ from targeting tubulin-sulfhydrils. Similar pattern of protection was also observed, when the cells preincubated with NAC acquired protection form STE-induced cytotoxicity and STE-mediated microtubule disruption were also inhibited to a significant extent (Fig. 9,10).

Although the experiments have been carried out with the transformed cell lines as in vitro models, the novelty of this study is that it aims to find out a specific target for STE-components, which may play an important role in STE-mediated tissue

\section{References}

1. Robertson PB, Walsh MM, Greene JC (1997) Oral effects of smokeless tobacco use by professional baseball players. Adv Dent Res 11: 307-312.

2. Bates C, Fagerström K, Jarvis MJ, Kunze M, McNeill A, et al. (2003) European Union policy on smokeless tobacco: A statement in favor of evidence based regulation for public health. Tob Control 12: 360-367.

3. Changrani J, Gany F (2005) Paan and Gutkha in the United States: An emerging threat. J. Immigrant Health 7: 103-108.

4. Richter P, Spierto FW (2003) Surveillance of smokeless tobacco nicotine, $\mathrm{pH}$, moisture, and unprotonated nicotine content. Nicotine Tobacco Res. 5: 885889.

5. Critchley JA, Unal B (2003) Health effects associated with smokeless tobacco: A systematic review. Thorax 58: 435-443.

6. Teo KK, Ounpuu S, Hawken S, Pandey MR, Valentin V, et al. (2006) INTERHEART Study Investigators. Tobacco use and risk of myocardial infarction in 52 countries in the INTERHEART study: A case-control study. Lancet $368: 647-658$.

7. Stepanov I. Jensen J, Hatsukami D, Hecht SS (2006) Tobacco-specific nitrosamines in new tobacco products. Nicotine Tob Res 8: 309-313.

8. Hoffmann D, Djordjevic MV (1997) Chemical composition and carcinogenicity of smokeless tobacco. Adv Dent Res 11: 322-329.

9. Hecht SS (1997) Tobacco and cancer: approaches using carcinogen biomarkers and chemoprevention. Ann N Y Acad Sci 833: 91-111.

10. Stepanov I, Jensen J, Hatsukami D, Hecht SS (2008) New and traditional smokeless tobacco: comparison of toxicant and carcinogen levels. Nicotine Tob Res 10: 1773-1782.

11. Stepanov I, Villalta PW, Knezevich A, Jensen J, Hatsukami D, et al. (2010) Analysis of 23 polycyclic aromatic hydrocarbons in smokeless tobacco by gas chromatography- mass spectrometry. Chem Res Toxicol 23: 66-73.

12. Bagchi M, Balmoori J, Bagchi D, Ray SD, Kuszynski C, et al. (1999) Smokeless tobacco, oxidative stress, apoptosis and antioxidants in human oral keratinocytes. Free Radic Biol Med 7: 992-1000.

13. Mitchell C, Joyce AR, Pipera JT, McKallip RJ, Fariss MW (2010) Role of oxidative stress and MAPK signaling in reference moist smokeless tobaccoinduced HOK-16B cell death. Toxicol Lett 19: 23-30.

14. Avti PK, Vaiphei K, Pathak CM, Khanduja KL (2010) Involvement of Various Molecular Events in Cellular Injury Induced by Smokeless Tobacco. Chem Res Toxicol 23: 1163-1174.

15. Costea DE, Lukandu O, Bui L, Ibrahim MJ, Lygre R, et al. (2010) Adverse effects of Sudanese toombak vs. Swedish snuff on human oral cells. J Oral Pathol Med. 39 : 128-40.

16. Lombard C, Farthing D, Sun J, Fariss MW, McKallip RJ (2010) Reference moist smokeless tobacco-induced apoptosis in human monocytes/macrophages cell line MM6. Int Immunopharmacol 10: 1029-1040.

17. Das A, Bhattacharya A, Chakrabarti G (2009) Cigarette Smoke Extract Induces Disruption of Structure and Function of Tubulin-Microtubule in Lung Epithelium Cells and in vitro. Chem Res Toxicol 22: 446-459.

18. Das A, Chakrabarty S, Choudhury D, Chakrabarti G (2010) 1,4-Benzoquinone (PBQ) Induced Toxicity in Lung Epithelial Cells is Mediated by the Disruption of the Microtubule Network and Activation of Caspase-3. Chem Res Toxicol 23: 1054-1066.

19. Das A, Choudhury D, Chakrabarty S, Bhattacharyya A, Chakrabarti G (2012) Acenaphthenequinone induces cell cycle arrest and mitochondrial apoptosis via disruption of cellular microtubule. Toxicol Res 1: 171-185. damage. Thus we may conclude that the active components present in STE may target and modify the reactive cysteine residues of tubulin, which subsequently leads to disruption and degradation of cellular microtubules and induces apoptosis in cultured mammalian cells.

\section{Acknowledgments}

Confocal Microscope and FACS instrument facilities are developed by grants from National Common Minimum Project, Govt. of India.

\section{Author Contributions}

Conceived and designed the experiments: AD AB GC. Performed the experiments: AD AB SC AG. Analyzed the data: AD AB SC AG GC. Contributed reagents/materials/analysis tools: GC. Wrote the paper: AD GC.

20. Nogales E, Whittaker M, Milligan RA, Downing KH (1999) High- resolution model of the microtubule, Cell 96: 79-88.

21. Kapoor TM, Compton DA (2002) Searching for the middle ground: Mechanisms of chromosome alignment during mitosis. J Cell Biol 157: 551-556. 22. Mitchison TJ (1989) Mitosis: Basic concepts. Curr Opin Cell Biol 1: 67-74.

23. Zhou J, Yao J, Joshi HC (2002) Attachment and tension in the spindle assembly checkpoint. J Cell Sci 115: 3547-3555.

24. Boutte AM, Woltjer RL, Zimmerman LJ, Stamer SL, Montine KS, et al. (2006) Selectively increased oxidative modifications mapped to detergent-insoluble forms of Abeta and beta-III tubulin in Alzheimer's disease. FASEB J. 20: 14731483.

25. Blanchard-Fillion B, Prou D, Polydoro M, Spielberg D, Tsika E, et al. (2006) Metabolism of 3-nitrotyrosine induces apoptotic death in dopaminergic cells. J Neurosci 26: 6124-6130.

26. Bernhard D, Csordas A, Henderson B, Rossmann A, Kind M, et al. (2005) Cigarette smoke metal-catalyzed protein oxidation leads to vascular endothelial cell contraction by depolymerization of microtubules. FASEB J. 19: 1096-1107.

27. Srivastava P, Panda D (2007) Rotenone inhibits mammalian cell proliferation by inhibiting microtubule assembly through tubulin binding. FEBS J. 274: 47884801 .

28. Landino LM, Koumas MT, Mason CE, Alston JA (2007) Modification of tubulin cysteines by nitric oxide and nitroxyl donors alters tubulin polymerization activity. Chem Res Toxicol 20: 1693-1700.

29. Poggi P, Rota MT, Boratto R (2002) The volatile fraction of cigarette smoke induces alterations in the human gingival fibroblast cytoskeleton. J Periodontal Res. 37: 230-235.

30. Mi L, Xiao Z, Hood BL, Dakshanamurthy S, Wang X, et al. (2008) Covalent binding to tubulin by isothiocyanates. A mechanism of cell growth arrest and apoptosis. J Biol Chem 283: 22136-22146.

31. Avti PK, Kumar S, Pathak CM, Vaiphei K, Khanduja KL (2006) Smokeless tobacco impairs the antioxidant defense in liver, lung, and kidney of rats, Toxicol Sci 89: 547-53.

32. Das A, Gopalakrishnan B, Voss OH, Doseff AI, Villamena FA (2012) Inhibition of ROS-induced apoptosis in endothelial cells by nitrone spin traps via induction of phase II enzymes and suppression of mitochondria-dependent pro-apoptotic signaling. Biochem Pharmacol 84: 486-497.

33. Chakrabarty S, Das A, Bhattacharya A, Chakrabarti G (2011) Theaflavins depolymerize microtubule network through tubulin binding and cause apoptosis of cervical carcinoma HeLa cells. J Agric Food Chem 59: 2040-2048.

34. Choudhury D, Das A, Bhattacharya A, Chakrabarti G (2010) Aqueous extract of ginger shows antiproliferative activity through disruption of microtubule network of cancer cells. Food Chem Toxicol 48: 2872-2880.

35. Bradford MM (1976) A rapid and sensitive method for the quantitation of micrograms quantities of protein utilizing the principle of protein-dye binding. Anal Biochem 72: 248-254.

36. Das A, Sinha S, Acharya BR, Paul P, Bhattacharyya B, et al, (2008) Deuterium oxide stabilizes conformation of tubulin:a biophysical and biochemical study. BMB Rep 41: 62-67.

37. Britto PJ, Knipling L, McPhie P, Wolff J (2005) Thiol-disulphide interchange in tubulin: kinetics and the effect on polymerization. Biochem J 389: 549-558.

38. Robinson AS, King J (1997) Disulphide- bonded intermediate on the folding and assembly pathway of a non-disulphide bonded protein. Nat Struct Biol 4: 450455 . 